\title{
New records and checklist of aquatic and semi-aquatic Heteroptera (Insecta: Hemiptera: Gerromorpha and Nepomorpha) from the Southern region of Mato Grosso do Sul, Brazil
}

\author{
Carla Fernanda Burguez Floriano ${ }^{1,2,4}$, Iana Aparecida Dalla Valle Oliveira ${ }^{2}$ \& Alan Lane de Melo ${ }^{3}$ \\ ${ }^{1}$ Zoology Department, Universidade Federal do Paraná - UFPR, CEP 80060-000, Curitiba, PR, Brazil \\ http://www.pgento.ufpr.br/ Bolsista CAPES \\ ${ }^{2}$ Group of Environmental Studies and Education GEAMBE, Universidade Estadual de Mato Grosso \\ do Sul-UFMS, CEP 79980-000, Mundo Novo, MS, Brazil. http://www.uems.br/portal/mundonovo.php \\ ${ }^{3}$ Parasitology Department, Biological Sciences Institute, Universidade Federal de Minas Gerais - UFMG, \\ CEP 31270-901, Belo Horizonte, MG, Brazil. http://www.icb.ufmg.br \\ ${ }^{4}$ Corresponding author: Carla Fernanda Burguez Floriano, e-mail: carlla.floriano@gmail.com
}

FLORIANO, C.F.B., OLIVEIRA, I.A.D.V. \& MELO, A.L. New records and checklist of aquatic and semiaquatic Heteroptera (Insecta: Hemiptera: Gerromorpha and Nepomorpha) from the Southern region of Mato Grosso do Sul, Brazil. Biota Neotrop. 13(1): http://www.biotaneotropica.org.br/v13n1/en/abstract?inve ntory+bn01813012013

\begin{abstract}
A list of aquatic and semi-aquatic Heteroptera species from the southern region of Mato Grosso do Sul State is presented. The material was collected between 2008 and 2009. Samples were obtained from 10 streams (Água Boa, Cerro Verde, Cumprida, Ponte, Doradão, Guaçú, Guaporites, Nhu-Verá, Perobão and Santa Maria), one river (Iguatemi River) and nine ponds (Bacal, Balan, Ponte, Cinco, Macrófitas, Bugão, Sítio, Cascalho, and Oxbow). A total of 63 aquatic and semi-aquatic species of Heteroptera were recorded, of which 32 are new records. Keywords: water-bug, aquatic insects, Iguatemi River.
\end{abstract}

FLORIANO, C.F.B., OLIVEIRA, I.A.D.V. \& MELO, A.L. Novos registros e checklist de Heteroptera semiaquáticos e aquáticos (Insecta: Hemiptera: Gerromorpha e Nepomorpha) para o Sul do Estado do Mato Grosso do Sul, Brasil. Biota Neotrop. 13(1): http://www.biotaneotropica.org.br/v13n1/pt/abstract?inventory+ bn01813012013

Resumo: Uma lista das espécies de Heteroptera aquáticos e semi-aquáticos para a região sul do Estado de Mato Grosso do Sul é apresentada. O material foi coletado entre 2008 e 2009. As amostras foram obtidas a partir de 10 córregos (Água Boa, Cerro Verde, Cumprida, Ponte, Doradão, Guaçú, Guaporites, Nhú-Verá, Perobão e Santa Maria), um rio (rio Iguatemi) e nove lagoas (Bacal, Balan, da Ponte, Cinco, Macrófitas, Bugão, Sítio, Cascalho, Oxbow). Um total de 63 espécies de heterópteros aquáticos e semi-aquáticos foram registrados, das quais 32 são novos registros.

Palavras-chave: percevejos aquáticos, insetos aquáticos, Rio Iguatemi. 


\section{Introduction}

Hemiptera is a group of hemimetabolous insects with some fossil members dating from the late Permian (Grimaldi \& Engel 2005). Currently, it comprises four suborders (Forero 2008), whose the referred suborder Heteroptera consist of insects having piercingsucking mouthparts inserted into the anterior part of the head and forewings, when present, of hemelytra type (Nieser \& Melo 1997, Gullan \& Cranston 2008). However, Gerromorpha is not divided into a leathery part (corium and clavus) and membranous apical part (membrane) (Andersen 1982).

The Heteroptera is a group of insects of great interest found worldwide (Nieser \& Melo 1997), except Antarctica (Polhemus \& Polhemus 2007, Schuh \& Slater 1995). Although most species have terrestrial habits, aquatic and semi-aquatic ones are also found (McCafferty 1981, Merrit \& Cummins 1984). Since 1555, about 4,800 species of Gerromorpha, Nepomorpha and Leptopodomorpha have been described (Polhemus \& Polhemus 2007). In the tropical South America, 700 species of Nepomorpha and Gerromorpha were cataloged (Pérez 1988), in Brazil 479 species were reported and in the Mato Grosso do Sul State were reported 27 species (Moreira et al. 2011).

The Brazilian States of Amazonas, Minas Gerais, Pará, Rio de Janeiro and Santa Catarina have the largest number of publications recording and or describing species of aquatic and semi-aquatic Heteroptera. In recent years, Espírito Santo and São Paulo were also subjected to studies with Veliidae (Moreira et al. 2010, Moreira \& Barbosa 2011), whereas few reports are available for other States. However, there are few records on the regional fauna and ecological studies about the various habitats of aquatic Heteroptera. Generally, such studies have been hampered by the lack of identification keys for the species of aquatic organisms.

For the State of Mato Grosso do Sul, there are records of some families in the Pantanal do Negro, in the Municipality of Aquidauana
(Bervian et al. 2006, Donald 2006, Silva et al. 2009), and families and genera in the southern region of the State (Floriano et al. 2008, 2009). However, studies of species are extremely scarse.

This study aimed to present a preliminary checklist of Gerromorpha and Nepormorpha species for the Mato Grosso do Sul State, in order to provide numerical data that will show the reality of regional species in Brazil.

\section{Materials and Methods}

The 2,940 km long Paraná River, originates in the junction of the Rivers Paranaíba and Grande, on the border of Mato Grosso do Sul, Minas Gerais and São Paulo (Godoy 1986), having as one of its main tributaries, the Iguatemi River, located in the extreme south of Mato Grosso do Sul State.

The Iguatemi River is $235 \mathrm{~km}$ long, presenting a meandering course, high water flow and several marginal lagoons near its mouth (Paiva 1982). The spring is located between the municipalities of Amambaí and Coronel Sapucaia, at about $520 \mathrm{~m}$ of altitude and flows into the Parana River at $226 \mathrm{~m}$ above sea level, between the municipalities of Eldorado, Mundo Novo and Guaíra, about $20 \mathrm{~km}$ above the ancient Salto das Sete Quedas (Súarez \& Petrere Junior 2003).

For the sampling activities three areas along the Iguatemi River were determined, these are, the upper region (Coronel Sapucaia and Amambai), middle region (Sete Quedas and Tacuru) and lower region (Mundo Novo, Japorã and Eldorado).

The illustrative locations of the sampling points are shown in Figure 1, and the geographical coordinates as well as the codes of the sampled areas are shown in Table 1.

For the upper region of the Iguatemi river five sampling points were determined, among them three were located in the Iguatemi River and two refer to the Nhu-Verá and Cumprida streams. As for the middle region, four sampling points were chosen (Iguatemi River,

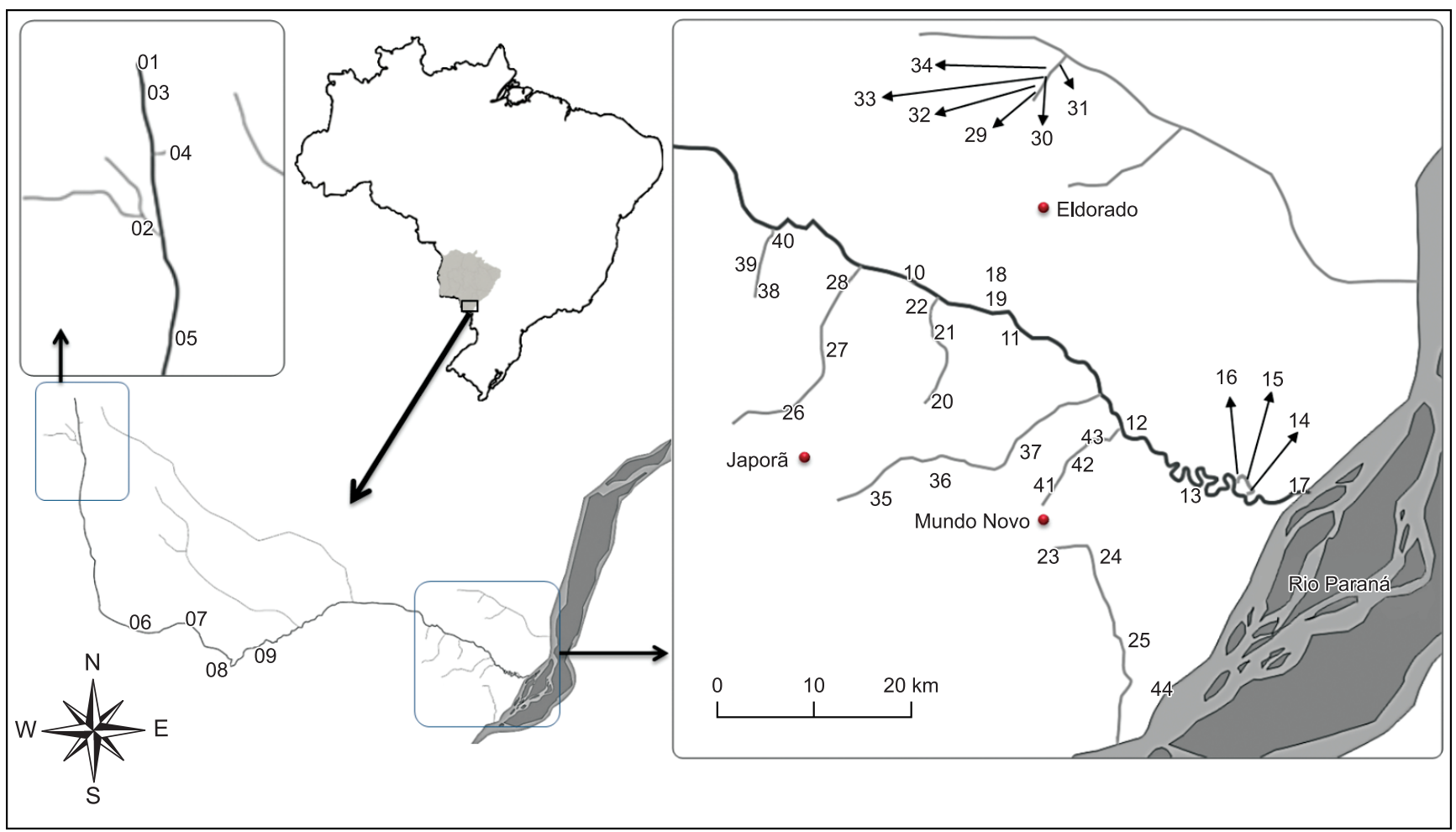

Figure 1. Map showing the 44 sampling sites in southern region of the Mato Grosso do Sul State. 
Table 1. Codes, names and geographical coordinates for 44 sampling sites in southern region of the Mato Grosso do Sul State.

\begin{tabular}{|c|c|c|c|c|}
\hline \multirow{2}{*}{ Region } & \multirow{2}{*}{ Code } & \multirow{2}{*}{ Site } & \multicolumn{2}{|c|}{ Geographical coordinates } \\
\hline & & & Latitude & Longitude \\
\hline \multirow[t]{5}{*}{ ARI } & $01-\mathrm{ARI}$ & Iguatemi River, sourcee & $23^{\circ} 13^{\prime} 24.1 "$ & $55^{\circ} 25^{\prime} 15.0^{\prime \prime}$ \\
\hline & $02-\mathrm{CN}$ & Nhu-Verá Stream & $23^{\circ} 18^{\prime} 48.1^{\prime \prime}$ & $55^{\circ} 25^{\prime} 16.3^{\prime \prime}$ \\
\hline & $03-\mathrm{ARI}$ & Iguatemi River & $23^{\circ} 13^{\prime} 41.8^{\prime \prime}$ & $55^{\circ} 25^{\prime} 17.4^{\prime \prime}$ \\
\hline & $04-\mathrm{CC}$ & Cumprida Stream * & $23^{\circ} 15^{\prime} 20.1 "$ & $55^{\circ} 25^{\prime} 04.0 \prime$ \\
\hline & $05-\mathrm{ARI}$ & Iguatemi River & $23^{\circ} 20^{\prime} 24.9^{\prime \prime}$ & $55^{\circ} 27^{\prime} 47.5^{\prime \prime}$ \\
\hline \multirow[t]{4}{*}{ MRI } & $06-\mathrm{MRI}$ & Iguatemi River & $23^{\circ} 47^{\prime} 37.1 ”$ & $55^{\circ} 06^{\prime} 30.8$ \\
\hline & $07-\mathrm{LB}$ & Bugão Lagoon * & $55^{\circ} 06^{\prime} 30.8^{\prime \prime}$ & $55^{\circ} 05^{\prime} 21.8^{\prime \prime}$ \\
\hline & $08-\mathrm{CV}$ & Cerro Verde Stream & $23^{\circ} 50^{\prime} 30.5^{\prime \prime}$ & $55^{\circ} 04^{\prime} 32.4^{\prime \prime}$ \\
\hline & $09-\mathrm{LC}$ & Cinco Lagoon $*$ & $23^{\circ} 53^{\prime} 30.6^{\prime \prime}$ & $55^{\circ} 00^{\prime} 16.6^{\prime \prime}$ \\
\hline \multirow[t]{35}{*}{ BRI } & $10-$ BRI & Iguatemi River & $23^{\circ} 49^{\prime} 01.33^{\prime \prime}$ & $54^{\circ} 22^{\prime} 05.7^{\prime \prime}$ \\
\hline & 11 - BRI & Iguatemi River & $23^{\circ} 50^{\prime} 22.3^{\prime \prime}$ & $54^{\circ} 19^{\prime} 31.0 \prime$ \\
\hline & $12-\mathrm{BRI}$ & Iguatemi River & $23^{\circ} 53^{\prime} 04.2 \prime$ & $54^{\circ} 15^{\prime} 38.1^{\prime \prime}$ \\
\hline & $13-\mathrm{BRI}$ & River Iguatemi & $23^{\circ} 55^{\prime} 09.5^{\prime \prime}$ & $54^{\circ} 12^{\prime} 50.7^{\prime \prime}$ \\
\hline & $14-\mathrm{LO}$ & Oxbow Lagoon & $23^{\circ} 55^{\prime} 22.6^{\prime \prime}$ & $54^{\circ} 11^{\prime} 19.0^{\prime \prime}$ \\
\hline & $15-\mathrm{LO}$ & Oxbow Lagoon & $23^{\circ} 55^{\prime} 11.4^{\prime \prime}$ & $54^{\circ} 11^{\prime} 15.4^{\prime \prime}$ \\
\hline & $16-\mathrm{LO}$ & Oxbow Lagoon & $23^{\circ} 54^{\prime} 53.8^{\prime \prime}$ & $54^{\circ} 11^{\prime} 25.3^{\prime \prime}$ \\
\hline & 17 - BRI & Iguatemi River, mouth & $23^{\circ} 55^{\prime} 36.1^{\prime \prime}$ & $54^{\circ} 09^{\prime} 60.1^{\prime \prime}$ \\
\hline & $18-\mathrm{LM}$ & Macrófitas Lagoon * & $23^{\circ} 49^{\prime} 11.5^{\prime \prime}$ & $54^{\circ} 20^{\prime} 01.9 \prime$ \\
\hline & $19-\mathrm{LP}$ & Ponte Lagoon * & $23^{\circ} 50^{\prime} 02.9^{\prime \prime}$ & $54^{\circ} 20^{\prime} 02.3^{\prime \prime}$ \\
\hline & $20-\mathrm{AB}$ & Água Boa Stream & $23^{\circ} 52^{\prime} 43.7^{\prime \prime}$ & $54^{\circ} 21^{\prime} 56.9^{\prime \prime}$ \\
\hline & $21-\mathrm{AB}$ & Água Boa Stream & $23^{\circ} 50^{\prime} 16.6^{\prime \prime}$ & $54^{\circ} 20^{\prime} 55.5^{\prime \prime}$ \\
\hline & $22-\mathrm{AB}$ & Água Boa Stream & $23^{\circ} 50^{\prime} 30.3^{\prime \prime}$ & $54^{\circ} 20^{\prime} 58.5^{\prime \prime}$ \\
\hline & $23-\mathrm{CP}$ & Ponte Stream & $23^{\circ} 56^{\prime} 45.9^{\prime \prime}$ & $54^{\circ} 17^{\prime} 28.2^{\prime \prime}$ \\
\hline & $24-\mathrm{CP}$ & Ponte Stream & $23^{\circ} 56^{\prime} 50.3^{\prime \prime}$ & $54^{\circ} 16^{\prime} 37.4^{\prime \prime}$ \\
\hline & $25-\mathrm{CP}$ & Ponte Stream & $23^{\circ} 59^{\prime} 48.5^{\prime \prime}$ & $54^{\circ} 15^{\prime} 22.7^{\prime \prime}$ \\
\hline & $26-\mathrm{CD}$ & Doradão Stream & $23^{\circ} 52^{\prime} 24.1^{\prime \prime}$ & $54^{\circ} 26^{\prime} 40.4^{\prime \prime}$ \\
\hline & $27-\mathrm{CD}$ & Doradão Stream & $23^{\circ} 51^{\prime} 04.9^{\prime \prime}$ & $54^{\circ} 25^{\prime} 13.9^{\prime \prime}$ \\
\hline & $28-\mathrm{CD}$ & Doradão Stream & $23^{\circ} 49^{\prime} 23.2^{\prime \prime}$ & $54^{\circ} 23^{\prime} 48.2^{\prime \prime}$ \\
\hline & $29-\mathrm{CA}$ & Guaporites Stream & $23^{\circ} 43^{\prime} 32.3^{\prime \prime}$ & $54^{\circ} 17^{\prime} 43.4^{\prime \prime}$ \\
\hline & $30-\mathrm{CA}$ & Guaporites Stream & $23^{\circ} 43^{\prime} 43.7^{\prime \prime}$ & $54^{\circ} 17^{\prime} 25.1^{\prime \prime}$ \\
\hline & $31-\mathrm{CA}$ & Guaporites Stream & $23^{\circ} 42^{\prime} 59.0 \prime$ & $54^{\circ} 17^{\prime} 10.3^{\prime \prime}$ \\
\hline & $32-\mathrm{LL}$ & Balan Lagoon * & $23^{\circ} 43^{\prime} 32.7^{\prime \prime}$ & $54^{\circ} 17^{\prime} 49.4^{\prime \prime}$ \\
\hline & $33-\mathrm{LA}$ & Bacal Lagoon * & $23^{\circ} 43^{\prime} 15.9^{\prime \prime}$ & $54^{\circ} 17^{\prime} 24.6^{\prime \prime}$ \\
\hline & $34-\mathrm{LS}$ & Sítio Lagoon* & $23^{\circ} 43^{\prime} 12.5 \prime$ & $54^{\circ} 17^{\prime} 29.5^{\prime \prime}$ \\
\hline & $35-\mathrm{CG}$ & Guaçú Stream & $23^{\circ} 55^{\prime} 04.1^{\prime \prime}$ & $54^{\circ} 23^{\prime} 40.7^{\prime \prime}$ \\
\hline & $36-\mathrm{CG}$ & Guaçú Stream & $23^{\circ} 54^{\prime} 19.6^{\prime \prime}$ & $54^{\circ} 21^{\prime} 43.4^{\prime \prime}$ \\
\hline & $37-\mathrm{CG}$ & Guaçú Stream & $23^{\circ} 53^{\prime} 31.4^{\prime \prime}$ & $54^{\circ} 18^{\prime} 42.3^{\prime \prime}$ \\
\hline & $38-\mathrm{BB}$ & Perobão Stream & $23^{\circ} 49^{\prime} 25.8^{\prime \prime}$ & $54^{\circ} 26^{\prime} 43.2^{\prime \prime}$ \\
\hline & $39-\mathrm{BB}$ & Perobão Stream & $23^{\circ} 48^{\prime} 59.4^{\prime \prime}$ & $54^{\circ} 26^{\prime} 43.2^{\prime \prime}$ \\
\hline & $40-\mathrm{BB}$ & Perobão Stream & $23^{\circ} 48^{\prime} 40.6^{\prime \prime}$ & $54^{\circ} 26^{\prime} 26.0^{\prime \prime}$ \\
\hline & $41-\mathrm{CF}$ & Santa Maria Stream & $23^{\circ} 55^{\prime} 22.7^{\prime \prime}$ & $54^{\circ} 17^{\prime} 49.5^{\prime \prime}$ \\
\hline & $42-\mathrm{CF}$ & Santa Maria Stream & $23^{\circ} 54^{\prime} 29.1$ ' & $54^{\circ} 17^{\prime} 14.4^{\prime \prime}$ \\
\hline & $43-\mathrm{CF}$ & Santa Maria Stream & $23^{\circ} 53^{\prime} 52.4^{\prime \prime}$ & $54^{\circ} 16^{\prime} 13.5^{\prime \prime}$ \\
\hline & $44-\mathrm{LH}$ & Cascalho Lagoon & $24^{\circ} 02^{\prime} 28.4^{\prime \prime}$ & $54^{\circ} 14^{\prime} 00.2^{\prime \prime}$ \\
\hline
\end{tabular}

*Names suggested by authors. ARI: upper region of Iguatemi River; MRI: middle region of Iguatemi River and BRI: low regions of Iguatemi River.

Cerro Verde stream, Bugão lagoon and Cinco lagoon). The sampling work in the upper and middle regions was carried out in February and May 2008, and February 2009.

Along the lower region of the Iguatemi River, ten sampling points were chosen, four in the river itself, three in the Oxbow lagoon, two in marginal lagoons (Macrófitas and Ponte) and one in the mouth. The collections were carried out in January, April, July and October 2008.

In the lower region seven streams were also investigated (Água Boa, Doradão, Guaçú, Guaporites, Perobão, Ponte, and Santa Maria).
For each stream, three sampling points were selected (near the source, in the middle region and near the mouth). As regards the frequency of collection, for the Doradão and Guacú streams, they were performed in a two-month period between February and October 2007. For the Perobão, Água Boa, Ponte and Santa Maria streams, the collections were quarterly, between March and December 2008. As for the Guaporites stream and the lagoons (Bacal, Balan, Ponte, Macrófitas, Cascalho and Sítio), samples were collected quarterly from September 2008 to June 2009. 
New records and checklist of aquatic and semi-aquatic Heteroptera

Table 2. Species of aquatic and semi-aquatic Heteroptera (Nepomorpha and Gerromorpha) recorded from the Mato Grosso do Sul State, with new records.

\begin{tabular}{l}
\hline \multicolumn{1}{c}{ Taxa } \\
Infraordem GERROMORPHA Popov, 1971 \\
Gerridae Leach, 1815
\end{tabular}

\section{Gerridae Leach, 1815}

Brachymetra furva Drake, 1957

Cylindrostethus palmaris Drake \& Harris, 1934

Halobatopsis platensis (Berg, 1879)

Limnogonus aduncus Drake \& Harris, 1933

Limnogonus ignotus Drake \& Harris, 1934

Limnogonus profugus Drake \& Harris, 1930

Neogerris lubricus (White, 1879)

Metrobates vigilis Drake \& Harris, 1945

Rheumatobates crassifemur Esaki, 1926

Hebridae Amyot \& Serville, 1843

Merragata hebroides White, 1877

Hydrometridae Billberg, 1820

Hydrometra argentina Berg, 1879

Mesoveliidae Douglas \& Scott, 1867

Mesovelia mulsanti White, 1879

Veliidae Amoyot \& Serville, 1843

Microvelia longipes Uhler, 1894

Microvelia mimula White, 1879

Microvelia pulchella Westwood, 1834

Platyvelia brachialis (Stål, 1860)

Rhagovelia hambletoni Drake, 1958

Rhagovelia tenuipes Champion, 1898

Rhagovelia whitei (Breddin, 1898)

Rhagovelia zela Drake, 1959

Steinovelia virgata (White, 1879)

Stridulivelia astralis (Drake \& Harris, 1938)

Xiphovelia lacunana (Drake \& Plaumann, 1953)

Infraordem NEPOMORPHA Popov 1971

Belostomatidae Leach, 1815

Belostoma bosque De Carlo, 1932

Belostoma dentatum (Mayr, 1863)

Belostoma dilatatum (Dufour, 1863)

Belostoma discretum Montandon, 1903

Belostoma elongatum Montandon, 1908

Belostoma foveolatum (Mayr, 1863)

Belostoma gestroi Montandon, 1900

Belostoma micantulum (Stål, 1858)

Belostoma pygmeum (Dufour, 1863)

Lethocerus annulipes (Herrich-Schäffer, 1846)

Lethocerus maximus De Carlo, 1838

L. melloleitaoi De Carlo, 1933

$\begin{array}{ll}X & X \\ X & X \\ X & X \\ X & X\end{array}$

$\mathrm{X}$

$\mathrm{X}$

$\mathrm{X}$

$\mathrm{X}$

$\mathrm{X}$

$\mathrm{X}$

$\mathrm{X}$

$\mathrm{X}$

X X

X

$\mathrm{X}$

X

X X

$\mathrm{X}$

$\mathrm{X}$

X

X

Corixidae Leach, 1815

Heterocorixa brasiliensis Hungerford, 1928

Tenagobia incerta Lundblad, 1928

Tenagobia schadei Lundblad, 1929

$\begin{array}{ll} & \\ & \\ & X \\ X & X \\ X & X \\ X & X \\ X & X \\ X & X \\ X & X\end{array}$

$\mathrm{X}$

$\mathrm{X}$

X

Gelastocoridae Champion, 1901

Gelastocoris amazonensis Melin, 1929

Gelastocoris flavus (Guérin-Méneville, 1835)

Gelastocoris monrosi De Carlo, 1959

$\mathrm{X}$

$\mathrm{X}$

$\mathrm{X}$

$\mathrm{X}$

Nerthra terrestris (Kevan, 1948)

Nerthra ranina (Herrich-Schäffer, 1853)

Naucoridae Fallén, 1814

RST: species registred in this study; SPR: species previously reported. 
Table 2. Continued...

\begin{tabular}{|c|c|c|c|}
\hline Taxa & New record & SRT & SPR \\
\hline Ambrysus bifidus La Rivers \& Nieser, 1972 & $\mathrm{X}$ & $\mathrm{X}$ & \\
\hline Limnocoris maculiceps Montandon, 1897 & & & $\mathrm{X}$ \\
\hline Limnocoris minutus De Carlo, 1951 & $\mathrm{X}$ & $\mathrm{X}$ & \\
\hline Pelocoris bipunctulus (Herrich-Schäffer, 1853) & & & $\mathrm{X}$ \\
\hline Pelocoris subflavus Montandon, 1898 & $\mathrm{X}$ & $\mathrm{X}$ & \\
\hline Placomerus micans La Rivers, 1956 & $\mathrm{X}$ & $\mathrm{X}$ & \\
\hline \multicolumn{4}{|l|}{ Nepidae Latreille, 1802} \\
\hline Curicta granulosa De Carlo, 1951 & & & $\mathrm{X}$ \\
\hline Curicta volxemi (Montandon, 1895) & & $\mathrm{X}$ & $\mathrm{X}$ \\
\hline Ranatra heydeni Montandon, 1909 & $\mathrm{X}$ & $\mathrm{X}$ & \\
\hline Ranatra horvathi Montandon, 1910 & & & $\mathrm{X}$ \\
\hline Ranatra rabida White, 1879 & & & $\mathrm{X}$ \\
\hline Ranatra siolii De Carlo, 1970 & $\mathrm{X}$ & $\mathrm{X}$ & \\
\hline \multicolumn{4}{|l|}{ Notonectidae Latreille, 1802} \\
\hline Buenoa amnigenus (White, 1879) & & & $\mathrm{X}$ \\
\hline Buenoa salutis Kirkaldy, 1904 & $\mathrm{X}$ & $X$ & \\
\hline Martarega brasiliensis Truxal, 1949 & $\mathrm{X}$ & $\mathrm{X}$ & \\
\hline Martarega membranacea White, 1879 & $\mathrm{X}$ & $\mathrm{X}$ & \\
\hline Martarega uruguayensis (Berg, 1883) & $\mathrm{X}$ & $\mathrm{X}$ & \\
\hline Notonecta pulchra Hungerford, 1926 & $\mathrm{X}$ & $\mathrm{X}$ & \\
\hline \multicolumn{4}{|l|}{ Pleidae Fieber, 1851} \\
\hline Neoplea maculosa (Berg, 1879) & $\mathrm{X}$ & $\mathrm{X}$ & \\
\hline Neoplea semipicta (Horváth, 1918) & $\mathrm{X}$ & $\mathrm{X}$ & \\
\hline
\end{tabular}

RST: species registred in this study; SPR: species previously reported.

The samples were taken by sweeping the water column, edges and bottom of the water bodies with entomological hand nets, when possible. The collected insects were sorted from detritus and transferred to vials containing $80 \%$ ethanol. In the laboratory, each sample was examined under a dissecting microscope and species identification was performed basically according to Nieser \& Melo (1997) and Heckman (2011). The sampled material was deposited in the Laboratório de Entomologia aquática da Universidade Estadual de Mato Grosso do Sul (UEMS) e Departamento de Parasitologia da Universidade Federal de Minas Gerais (DPIC).

\section{Results and Discussion}

A total of 42 aquatic and semi-aquatic Heteroptera species (18 Gerromorpha, 24 Nepomorpha) were recorded, of which 32 are new records for the Mato Grosso do Sul State. A list of the species, grouped in 29 genera and distributed in 12 is presented (List 1 and Table 2).

The family of Gerromorpha with the greatest number of species was Gerridae with eight species, followed by Veliidae with seven. Among the Nepomorpha, Belostomatidae showed the highest richness, with seven species (five of Belostoma and two of Lethocerus).

Pleidae, which features small species that do not exceed three millimeters in length, are not frequently collected by not specialist, due to either their size or because they are rare or even their specific habitat. Thus, there are few records of their geographical distribution. Nevertheless, two species of Neoplea were registered in the State.

The State now contains 63 species of aquatic and semi-aquatic Heteroptera, with 10 species being recorded again in our studies, which were: Belostoma dilatatum (Dufour, 1863) (Ribeiro 2007), B. discretum Montandon, 1903 (Ribeiro 2007), B. elongatum Montandon, 1908 (Ribeiro 2007), B. micantulum (Stål, 1860)
(Ribeiro 2007), Curicta volxemi (Montandon, 1895) (Heckman 2011), Hydrometra argentina Berg, 1879 (Moreira et al. 2009, Heckman 2011), Lethocerus maximus De Carlo, 1938 (Ribeiro 2005, Heckman 2011), Limnogonus profugus Drake \& Harris, 1930 (Heckman 2011), Microvelia pulchella Westwood, 1834 (Drake \& Plaumann 1953), Tenagobia incerta Lundblad, 1929 (Nieser 1977) (Table 2).

The species B. bosqi De Carlo, 1932 (Ribeiro 2007), B. dentatum (Mayr, 1863) (Nieser 1975), B. foveolatum (Mayr, 1863) (Ribeiro 2007), B. gestroi Montandon, 1900 (Ribeiro 2004), Buenoa amnigenus (White, 1879) (Heckman 2011), C. granulosa De Carlo, 1951 (Heckman 2011), Gelastocoris amazonensis Melin, 1929 (Schnack \& Estévez 1979), G. monrosi De Carlo, 1959 (De Carlo 1959), Heterocorixa brasiliensis Hungerford, 1928 (Hungerford 1948), L. melloleitaoi De Carlo, 1933 (Heckman 2011), Limnocoris maculiceps Montandon, 1897 (Heckman 2011), L. ignotus Drake \& Harris, 1934 (Heckman 2011), M. longipes Uhler, 1894 (Drake \& Plaumann 1953), M. mimula White, 1879 (Drake \& Plaumann 1953, Heckman 2011), Nerthra terrestris (Kevan, 1948) (Heckman 2011), Pelocoris bipunctulus (Herrich-Schäffer, 1853) (Heckman 2011), Ranatra horvathi Montandon, 1910 (Nieser \& Melo 1997), R. rabida White, 1879 (Heckman 2011), Stridulivelia astralis (Drake \& Harris, 1938) (Heckman 2011), T. schadei Lundblad, 1929 (Hungerford 1948), Xiphovelia lacunana (Drake \& Plaumann, 1953) (Drake \& Plaumann 1953) were previously reported, however, unregistered in this study (Table 2).

According to Moreira et al. (2011), species Pelocoris binotulatus nigriculus Berg, 1879 and Lipogomphus lacuniferus Berg, 1879, possibly occurring in the State, but were not recorded in the sampling points, there is the possibility that these species occur further north of the State. 
For records of species occurrence $G$. amazonensis, G. monrosi 1959, M. longipes, M. mimula, M. pulchella Westwood, 1834 and $X$. lacunana, the same were performed before the geopolitical division of the State in 1977. However, today these localities belong to the State of Mato Grosso do Sul (Moreira et al. 2011).

The Mato Grosso do Sul State has an important regional fauna of water bugs on the current records. However, knowledge about the aquatic and semi-aquatic Heteroptera in the State is still scarce. Further studies are necessary and important in order to provide numerical data that contribute to the reality of regional species in Brazil.

\section{Acknowledgements}

The authors wish to thank the Dr. Valéria Flávia Batista da Silva for coordinating the development of the project; Dr. Jelly Makoto Nakagaki for the guidance provided in the development of the work; Fernando Zimmer Waslawick for preparing the illustrative map. To the Estadual University of Mato Grosso do Sul, CIABRI and FUNDECT for financial support, and the Municipalities Coronel Sapucaia, Japorã, Mundo Novo, and Tacuru (MS) for logistical support in the collection work.

\section{References}

ANDERSEN, N.M. 1982. The Semiaquatic Bugs (Hemiptera, Gerromorpha) Phylogeny, Adaptations, Biogeography and Classification. Entomonograph 3:1-455.

BERVIAN, B., INACIO, C., PEDOTTI-STRIQUER, L. \& FAVERO, S. 2006. Heterópteros (Insecta) aquáticos e semi-aquáticos associados a Salvinia auriculata (Salviniaceae) em três ambientes do pantanal do Negro, município de Aquidauna, MS. Ensaios Ciênc. 10(1):143-152.

DE CARLO, J.A. 1959. Géneros Gelastocoris y Montandonius (HemipteraGelastocoridae) revisión de las espécies de Guérin y De Carlo consideradas sinónimas. Acta Zool. Lilloana 17:53-85.

DONALD, P.E. 2006. Contribuição para conservação de macroinvertebrados, peixes, e habitats de água doce no pantanal de Nhecolândia e do rio Negro, Mato Grosso do Sul. Ensaios Ciênc. 10(1):99-118.

DRAKE, C.J. \& PLAUMANN, F. 1953. A new waterstrider from Brazil (Hemiptera: Veliidae). Dusenia 4(5-6):414-416.

FLORIANO, C.F.B., VIDOVIX, T.A.S. \& OLIVEIRA, I.A.D.V. 2008. Levantamento preliminar das famílias de Heteroptera (Hemiptera), em dois substratos distintos, sub-bacia do rio Iguatemi/MS. In Anais XXII Congresso Brasileiro de Entomologia. Sociedade Brasileira de Entomologia, Uberlândia. CD-ROM.

FLORIANO, C.F.B., OLIVEIRA, I.A.D.V. \& CRUZ, G.K. 2009. Heterópteros aquáticos e semi-aquáticos em quatro córregos distintos da região sul do estado de Mato Grosso do Sul. In Anais $19^{\circ}$ Congresso de Biológos do CRBio. São Pedro, p.132-133.

FORERO, D. 2008. The systematics of the Hemiptera. Rev. Colomb. Entomol. 34(1):1-21.

GODOY, M.P. 1986. Peixes e pesca do rio Paraná: área do futuro reservatório de Ilha Grande. Eletrosul, Florianópolis.

GRIMALDI, D. \& ENGEL, M. S. 2005. Evolution of the Insects. Cambridge University Press, New York.

GULLAN, P.J. \& CRANSTON, P.S. 2008. Os insetos: um resumo de entomologia. Rocca, São Paulo.

HECKMAN, C.W. 2011. Encyclopedia of South American Aquatic Insects: Hemiptera-Heteroptera Illustrated Keys to Known Families, Genera, and Species in South America. Springer, London, New York. http://dx.doi. org/10.1007/978-94-007-0705-4
HUNGERFORD, D.B. 1948. The Corixidae of the Western Hemisphere (Hemiptera). Univ. Kans. Sci. Bull. 32: 5-827.

McCAFFERTY, W.P. 1981. Aquatic entomology. Jones and Barlett, Sudbury.

MERRIT, R.W. \& CUMMINS, K.W. 1984. An introduction to the aquatic insects of North America. Kendall, Hunt Publ. Co, Dubuque.

MOREIRA, F.F.F., NESSIMIAN, J.A., RÚBIO, J.A., \& SALLES, F.F. 2010. New species and new records of Veliidae from Espírito Santo State and adjacente Minas Gerais State, Brazil, with notes on nomenclature (Insecta: Heteroptera: Gerromorpha). J. Nat. Hist. 44(45-46):2761-2801. http:// dx.doi.org/10.1080/00222933.2010.512423

MOREIRA, F.F.F. \& BARBOSA, J.F. 2011. The Veliidae (Hemiptera: Heteroptera: Gerromorpha) from São Paulo State, Brazil: new species, description of the male of Microvelia ioana Drake \& Hottes, 1952, and synonymical and distributional notes. Ann. Limnol. 47(3):297-311. http:// dx.doi.org/10.1051/limn/2011010

MOREIRA, F.F.F., BARBOSA, J.F., RIBEIRO, J.R.I. \& ALECRIM, V.P. 2011. Checklist and distribution of semiaquatic and aquatic Heteroptera (Gerromorpha and Nepomorpha) occurring in Brazil. Zootaxa 2958:1-74.

MOREIRA, F.F.F., RIBEIRO, J.I. \& NESSIMIAN, J.L. 2009. A synopsis of the Hydrometra (Hemiptera, Heteroptera, Hydrometridae) fron the Amazon River floodplain, Brazil, with redescription of Hydrometra argentina Berg. Acta Amazon. 53(1):69-73.

NIESER, N. 1975. The water bugs ( Heteroptera: Nepomorpha) of the Guyana Region. Stud. fauna Suriname other Guyanas 16(59):1-303.

NIESER, N. 1977. A revision of the genus Tenagobia Bergroth (Heteroptera: Corixidae). Stud. Neotr. Fauna Envir. 12(1):1-56. http://dx.doi org/10.1080/01650527709360510

NIESER, N. \& MELO, A.L, 1997. Os Heterópteros Aquáticos de Minas Gerais - Guia Introdutório com Chave de Identificação para as Espécies de Nepomorpha e Gerromorpha. UFMG, Belo Horizonte.

PAIVA, M.P. 1982. Grandes represas do Brasil. Editerra, Brasília.

PÉREZ, G. R. 1988. Guia para el estudio de los macroinvertebrados acuáticos del Departamento de Antioquia. Editorial Presencia Ltda, Bogotá.

POLHEMUS, J.T. \& POLHEMUS, D.A. 2007. Global trends in the description of aquatic and semi aquatic Heteroptera species, 1758-2004. Tijdschr Entomol. 150:271-288. http://dx.doi.org/10.1163/22119434-900000230

RIBEIRO, J.R.I. 2004. Redescription and taxonomic considerations of Belostoma gestroi Montandon, 1900 (Heteroptera: Belostomatidae). Stud. Neotr. Fauna Envir. 39(1):53-56. http://dx.doi.org/10.1080/0165 0520412331270972

RIBEIRO, J.R.I. 2005. Família Belostomatidae Leach, 1815 (Insecta: Hemiptera: Heteroptera): Chave e catálogo de identificação para as espécies ocorrentes no estado do Rio de Janeiro, Brasil. Arq. Mus. Nac. 63(2):247-262.

RIBEIRO, J.R.I. 2007. A review of the species of Belostoma Latreille, 1807 (Hemiptera: Heteroptera: Belostomatidae) from the four southeastern Brazilian states. Zootaxa 1477:1-70.

SILVA, F.H., FAVERO, S., SABINO, J. \& GARNÉS, S.J.A. 2009. Distribuição da entomofauna associada às macrófitas aquáticas na vazante do rio Correntoso, Pantanal do Negro, Estado do Mato Grosso do Sul, Brasil Acta Sci., Biol. Sci. 31(2):127-134.

SCHNACK, J.A. \& ESTÉVEZ, A.L. 1979. Monografia sistematica de los Gelastocoridae de la República Argentina (Hemiptera). Limnobios 1(9):346-380.

SCHUH, R. T. \& SLATER, J.A. 1995. True Bugs of the World (Hemiptera: Heteroptera): Classification and Natural History. Comstock Publishing Associates, London.

SÚAREZ, Y.R. \& PETRERE JUNIOR, M. 2003. Associações de espécies de peixes em ambientes lóticos da bacia do rio Iguatemi, Estado do Mato Grosso do Sul. Acta Sci., Biol. Sci. 25(2):361-367. 


\section{Appendix}

List 1. Species of aquatic and semi-aquatic Heteroptera (Nepomorpha and Gerromorpha) collected and identified for 44 sampling sites in southem region of the Mato Grosso do Sul State. $(*)$ species previously reported.

\section{Infraordem GERROMORPHA Popov, 1971}

\section{Gerridae Leach, 1815}

Brachymetra furva Drake, 1957

Ocurrence: AB; ARI; BRI; CA; CC; CD; CF; CG; CV; MRI.

One specimen: 'CF P3 FA 12-08\Brachymetra $\backslash$ furva'; 13 specimens: ‘ARI $\backslash$ P1 PE 01.09\B. furva'; Two specimens: 'AB P1 PE 12.08 Brachymetra $\backslash$ furva'; Two specimens: 'P6 FA 06.08 $\backslash$ B. furva'; One specimen: 'BRI P8 FA $\backslash$ Brachymetra $\backslash$ furva'; Six specimens: 'P6 FA 06.09\B. furva'; One specimen: 'P2 FA 03.09\B. furva'; Three specimens: 'P6 PE 06.09\Brachymetra $\backslash$ furva'; One specimen: 'P6 PE CA 06.08\B. furva'; Six specimens: 'P6 FA 12.08\Brachymetra \furva'; One specimen: 'P6 FA 06.09\B. furva'; One specimen: 'P3 FA 06.08 $\backslash$ Brachymetra $\backslash$ furva'; One specimen: 'P6 FA 06.08 $\backslash$ B. furva'; Three specimens: 'P6 FA 03.09 $B$. furva'; One specimen: 'P3 FA $12.08 \backslash$ B. furva'; Three specimens: 'P2 PE 12.08\B. furva'; 10 specimens: 'P2 PE 03.09 B. furva'; Eight specimens: 'P2 FA 03.09 $B$. furva'; One specimen: 'CF P3 PL 09.08\Brachymetra furva'; One specimen: 'AB PE P2 06.08\Brachymetra furva'; Three specimens: 'AB PE P2 06.08\Brachymetra furva'; Two specimens: 'AB P1 PE 09.08\Brachymetra furva'; Seven specimens: 'AB P3 PE 09.08 Brachymetra furva'; Two specimens: 'CF P2 PE 12.08\Brachymetra furva'; One specimen: 'BRI P2 PE 02.08\B. furva'; One specimen: 'AB P1 PL 12.08\B. furva'; Four specimens: 'AB P1 FA 09.08\B. furva'; One specimen: 'ARI P2 PE 01.09 $\backslash$ B. furva'; Nine specimens: 'CF PE P3 06.08\Brachymetra $\backslash$ furva'; One specimen: 'CG P1 FA 02.07\Brachymetra'; One specimen: 'MRI P3 P2 05.08\B. furva'; One specimen: 'AB P2 FA 03.08 $\backslash$ B. furva'; One specimen: 'BRI P3 PL 05.08\ B. furva'; Two specimens: 'ARI P4 PE 05.08\ B. furva'; Five specimens: 'ARI P1 FA 05.08\Brachymetra furva'; Two specimens: 'AB P2 FA 03.08\Brachymetra furva'; One specimen: 'CF PE P1 06.08\B. furva'; One specimen: 'MRI P3 PL 05.08\B. furva'; 20 specimens: 'ARI FA P1 09.08 $\backslash$ B. furva'; One specimen: 'CD PE P3 02.07 Gerridae \Brachymetra'; Eight specimens: 'ARI $\backslash$ P4 FA 01.09\B. furva'; Three specimens: 'ARI P4 PE 01.09\Gerridae Brachymetra'; One specimen: 'P3 FA 12.08 $\backslash$ B. furva'; One specimen: 'AB P3 FA 09.08\Brachymetra furva'; One specimen: 'CF P3 FA 06.08\Brachymetra furva'; One specimen: 'AB P3 FA 06.08\Brachymetra furva'; One specimen: 'AB PE P2 03.08\Brachymetra furva'; Three specimens: 'ARI PL P1 01.09\B. furva'; Three specimens: 'ARI PL P1 01.09\B. furva'; One specimen: 'ARI P3 PE 01.09\ B. furva'; Three specimens: 'CF P3 PL 06.08\Brachymetra furva'.

Cylindrostethus palmaris Drake \& Harris, 1934

Ocurrence: CV; MRI.

Three specimens: 'MRI P2 FA 05.08 $\backslash$ C. palmaris'; Five specimens: 'MRI P3 FA 05.08 C. palmaris'.

Halobatopsis platensis (Berg, 1879)

Ocurrence: AB; ARI; CA; CF; LC; MRI.

Two specimens: 'MRI P1 FA 05.08\Halobatopsis \platensis'; Four specimens: 'P3 PE 06.09 $\backslash$ H. platensis'; One specimen: 'CA P3 SD 03.08 $\backslash$ H. platensis'; Three specimens: 'MRI P4 FA 05.08 $\backslash$ H. platensis'; One specimen: 'CF P3 FA 09.08 $\backslash$ H. platensis'; One specimen: 'ARI P3 FA 05.08\H. platensis'; One specimen: 'AB P3 FA 09.08\H. platensis'; One specimen: 'MRI P3 PE 02.08 $\backslash$ H. platensis'; One specimen: 'MRI FA 05.08\H. platensis'; One specimen: 'ARI P5 PE 01.09\H. platensis'.

Limnogonus aduncus Drake \& Harris, 1933

Ocurrence: CA; CF; LL; LO; LM; LS.

Two specimens: 'CF PE P3 06-08\Limnogonus $\backslash$ aduncus'; One specimen: 'P2 PE 03.09 $\backslash$ L. aduncus'; One specimen: 'P4 PE 06.08 L. aduncus'; Two specimens: 'P4 PE 12.08 $\backslash$ L. aduncus'; One specimen: 'P1 PE CA 12.08 $\backslash$ Limnogonus $\backslash$ aduncus'; Two specimens: 'P6 FA 03.09\L. aduncus'; One specimen: 'BRI P5 PE 10.08\L. aduncus'.

Limnogonus profugus Drake \& Harris, 1930*

Ocurrence: AB; BB; CA; CF; LA; LB; LO; LS.

Three specimens: 'BB P2 PE 06-08\Limngonus $\backslash$ profugus'; Three specimens: 'AB P2 PE 09-08\Limnogonus $\backslash$ profugus'; Seven specimens: 'P5 FA 06.09\L. profugus'; Three specimens: 'P5 FA 06.09\Limnogonus $\backslash$ profugus'; One specimen: ' P2 FA $12.08 \backslash$ L. profugus'; Four specimens: 'P6 FA 03.09 L. profugus'; One specimen: 'P6 PE 06.09 L. profugus'; One specimen: ‘AB P1 PL 06.08 $\backslash$ L. profugus'; One specimen: 'MRI P2 PE 05.08 L. profugus'; One specimen: 'BB P2 PL 09.08\L. profugus'; One specimen: 'AB P1 FA 06.08 $\backslash$ L. profugus'; One specimen: 'P4 PE 12.08\L. profugus'; One specimen: 'BB P1 PL 09.08 L. profugus'; One specimen: 'BB PL P3 06.08 $\backslash$ L. profugus'; One specimen: 'BB P3 FA 09.08 $\backslash$ L. profugus'; One specimen: 'BB P1 FA 09.08 $\backslash$ L. profugus'; One specimen: 'AB P3 PE 06.08\L. profugus'; Two specimens: 'BB P1 PL 09.08\Limnogonus profugus'; One specimen: 'BB P1 PL 06.08\Limnogonus $\backslash$ profugus'; One specimen: 'P5 FA 12.08 $\backslash$. profugus'; One specimen: 'BB P2 PL 06.08\L. profugus'; One specimen: 'BRI P5 FA 10.08 L. profugus'; Two specimens: 'CF P3 PE 09.08\L. profugus'.

Neogerris lubricus (White, 1879)

Ocurrence: LO; LS.

Two specimens: 'BRI P5 PE 07.08\N. lubricus'; One specimen: 'P4 FA 12.08 $\backslash$ N. lubricus'. 
Metrobates vigilis Drake \& Harris, 1945

Ocurrence: ARI, BRI; MRI.

One specimen: 'BRI P1 FA 07.08\Metrobates $\backslash$ vigilis'; One specimen: 'BRI P2 FA 02.09\M. vigilis'; Five specimens: 'MRI P4 FA 05.08 $\backslash$ M. vigilis'; Eight specimens: 'BRI P3 PE 10.08\M. vigilis'; Two specimens: 'ARI P1 FA 06.08 $\backslash M$. vigilis'; Three specimens: 'BRI P1 FA 01.08\M. vigilis'.

Rheumatobates crassifemur Esaki, 1926

Ocurrence: BRI; LO; LS; MRI.

One specimen: 'BRI P3 PE 10-08 $\backslash R$. crassifemur'; One specimen: 'BRI P7 FA 10-08 $\backslash R$. crassifemur'; Four specimens: 'MRI P1 PE 01.09 $\backslash R$. crassifemur'; One specimen: 'MRI P3 FE 01.09 $\backslash R$. crassifemur'. Nine specimens: 'P4 P3 FA 03.09 $\backslash$ Rhematobates'.

\section{Hebridae Amyot \& Serville, 1843}

Merragata hebroides White, 1877

Ocurrence: LA.

Seven specimens: 'LN $\backslash \mathrm{PE} \backslash 06.08 \backslash$ M. hebroides'.

\section{Hydrometridae Billberg, 1820}

Hydrometra argentina Berg, 1879*

Ocurrence: BRI; LA.

One specimen: 'BRI P7 PE 04.08 $\backslash$ Hydrometridae $\backslash H$. argentina'; Five specimens: 'BRI P6 PE 10.08\Hydrometridae $\backslash$ Hydrometra'; One specimen: 'P1 PE CA\Hydrometra' 'Hydrometra argentina $\backslash$ Berg, 1879'.

\section{Mesoveliidae Douglas \& Scott, 1867}

Mesovelia mulsanti White, 1879

Ocurrence: LO; CA.

One specimen: 'BRI P5 PE 07.08\Mesoveliidae \Mesovelia mulsanti'; One specimen 'P3 PE 12.08 CA $\backslash$ Mesovelia $\backslash$ mulsanti'.

Veliidae Amoyot \& Serville, 1843

Microvelia pulchella Westwood, 1834*

Ocurrence: LA.

Four specimens: 'P5 PE 12.05' Microvelia'; Two specimens: 'P5 FA 06.09\Microvelia'; One specimen: LN PE 09.08\Microvelia'.

Platyvelia brachialis (Stål, 1860)

Ocurrence: BB.

One specimen: 'BB P2 P2 03-08\Platyvelia $\backslash$ P. brachialis'.

Rhagovelia hambletoni Drake, 1958

Ocurrence: AB; BRI.

Two specimens: 'BRI P4 FA 07.08\Veliidae $\backslash$ Rhagovelia' 'Rhagovelia hambletoni'; One specimen: 'BRI P8 PE $10.08 \backslash$ Veliidae Rhagovelia' ' $R$. hambletoni'; One specimen: 'AB P3 PE 06.09\Veliidae $\backslash$ Rhagovelia $\backslash$ R. hambletoni'; One specimen: 'BRI P2 PE $10.08 \backslash$ Veliidae $\backslash$ Rhagovelia hambletoni'; 30 specimens: 'BRI P4 FA 10.08 $\backslash$ R. hambletoni'; Two specimens: 'AB P3 PE 06.08 $\backslash$ R. hambletoni'.

Rhagovelia tenuipes Champion, 1898

Ocurrence: CN; BRI.

18 specimens: 'BRI PE FA 07.08z Rhagovelia $\backslash$ tenuipes'; Seven specimens: 'BRI P2 FA 07.08\ Rhagovelia $\backslash$ hambletoni'; One specimen: 'ARI P3 FA 05.08\Veliidae $\backslash$ Rhagovelia'.

Rhagovelia whitei (Breddin, 1898)

Ocurrence: CF.

11 specimens: 'CF P1 P2 12-08\Rhagovelia' 'R. whitei'.

Rhagovelia zela Drake, 1959

Ocurrence: $\mathrm{CC}$; $\mathrm{CF}$.

12 specimens: 'CF PE 09-08\Rhagovelia' 'R. zela'; Three specimens: 'ARI P4 PE 05.08\Veliidae $\backslash$ Rhagovelia $\backslash$ R. zela'.

Steinovelia virgata (White, 1879)

Ocurrence: $\mathrm{CF}$

Two specimens: 'CF P1 PE 06.08\Veliidae \Steinovelia'.

\section{Infraordem NEPOMORPHA Popov 1971}

Belostomatidae Leach, 1815

Belostoma dilatatum (Dufour, 1863)*

Ocurrence: CF; BRI. 
Floriano, C.F.B. et al.

One specimen: 'BRI P5 PE 07.08\Belostoma' 'B. dilatatum'; Four specimens: 'CF PE Belostomatidae $\backslash$ B. dilatatum $\backslash$ (Dufour, 1863).

Belostoma discretum Montandon, 1903*

Ocurrence: BRI; CP.

One specimen: 'CP P3 PE 03.08\Belostoma' 'B. discretum'; One specimen: 'BRI PE $\backslash$ Belostomatidae $\backslash$ Belostoma' 'Belostoma discretum $\backslash$ Montandon, 1903'.

Belostoma elongatum Montandon, 1908*

Ocurrence: BB.

Two specimens: 'BB P2 PL 06.08\Belostoma' 'BB P2 PL 06.08\Belostoma elongatum'; Two specimens: 'BB P1 PE 06.08\Belostoma' 'Belostoma elongatum'.

Belostoma micantulum (Stål, 1858) *

Ocurrence: BRI.

One specimen: 'BRI P4 PE 10.08\B. micantulum'.

Belostoma pygmeum (Dufour, 1863)

Ocurrence: LO.

One specimen: 'BRI P6 PE 07.08\Belostoma pygmeum'.

Lethocerus annulipes (Herrich-Schäffer, 1846)

Ocurrence: CP.

One specimen: 'CP PL \Belostomatidae $\backslash$ Lethocerus' 'Lethocerus annulipes $\backslash$ (Herrich-Schäffer, 1846)'.

Lethocerus maximus De Carlo, 1838*

Ocurrence: CP.

One specimen: 'CP PL \Belostomatidae $\backslash$ Lethocerus' 'L. maximus'.

\section{Corixidae Leach, 1815}

Tenagobia incerta Lundblad, 1928*

Ocurrence: BB.

Eight specimens: 'BB P1 FA 09.08\Tenagobia $\backslash$ incerta'.

\section{Gelastocoridae Champion, 1901}

Gelastocoris flavus (Guérin-Méneville, 1835)

Ocurrence: BB.

One specimen: 'BB P3 PE 12.08\Gelastocoris' 'Gelastocoris flavus flavus (G. Méneville)'.

Nerthra ranina (Herrich-Schäffer, 1853)

Ocurrence: MRI.

One specimen: 'MRI PE 02.08\Nerthra' 'Nerthra ranina $\backslash$ (Herrich-schaffer)'; One specimen: 'MRI P4 PE 02.08 $\backslash$ Nerthra ranina' 'Nerthra ranina $\backslash$ (Herrich-schaffer)'.

\section{Naucoridae Fallén, 1814}

Ambrysus bifidus La Rivers \& Nieser, 1972

Ocurrence: AB.

Two specimens: 'AB PE $\backslash$ Naucoridae $\backslash$ Ambrysus' 'Ambrysus bifidus'.

Limnocoris minutus De Carlo, 1951

Ocurrence: BRI; MRI.

Two specimens: 'BRI P7 PE 01.08\Limnocoris $\backslash$ minutus'; One specimen: 'MRI P4 SDP 05.08\Limnocoris $\backslash$ minutus'.

Pelocoris subflavus Montandon, 1898

Ocurrence: LH.

Four specimens: 'L. Cascalho $\backslash$ Pelocoris $\backslash$ subflavus'.

Placomerus micans La Rivers, 1956

Ocurrence: LA.

Five specimens: 'LN PE CA $\backslash$ Placomerus $\backslash$ micans'.

Nepidae Latreille, 1802

Curicta volxemi (Montandon, 1895)*

Ocurrence: LH.

One specimen: 'L. Cascalho' 'Patty' 'Curicta volxemi (Montandon, 1895)'. 
Ranatra heydeni Montandon, 1909

Ocurrence: CD.

One specimen: 'CD' 'Ranatra $\backslash$ heydeni $\backslash$ Montandon'.

Ranatra siolii De Carlo, 1970

Ocurrence: AB.

One specimen: 'CD PE $\backslash$ Ranatra' 'Ranatra siolii $\backslash$ De Carlo 1970'.

Notonectidae Latreille, 1802

Buenoa salutis Kirkaldy, 1904

Ocurrence: CD; LO.

Four specimens: 'BRI P6 PE. 07.08\Buenoa' 'B. salutis'; One specimen: 'CD P3 PE 04.07 Buenoa' 'B. salutis'.

Martarega brasiliensis Truxal, 1949

Ocurrence: BRI.

Three specimens: 'BRI P3 PE 10.08\Martarega' 'Martarega $\backslash$ brasiliensis $\backslash$ Truxal, 1949'; Two specimens: 'BRI P2 FA $04.08 \backslash$ Martarega brasiliensis'; Five specimens: 'MRI P3 FA 05.08\Martarega' 'M. uruguayensis'; One specimen: 'BRI P5 FA $07.08 \backslash$ M. brasiliensis'; Two specimens: 'BRI P4 PE 10.08\Martarega' 'M. brasiliensis'.

Martarega membranacea White, 1879

Ocurrence: LO.

Two specimens: 'BRI P7 FA 04.08\Martarega sp2' 'Martarega $\backslash$ membranacea $\backslash$ White, 1879'; One specimen: 'BRI P7 FA 07.08 Martarega' 'Martarega $\backslash$ membranacea $\backslash$ White, 1879'; Three specimens: 'BRI P7 FA $\backslash$ M. membranacea'; One specimen: 'BRI P5 PE 04.08\M. membranacea'; Two specimens: 'BRI P8 PE 04.08\Martarega' 'M. membranacea'.

Martarega uruguayensis (Berg, 1883)

Ocurrence: ARI; BB; BRI; MRI; CA; CV; LO.

One specimen: 'ARI P4 FA 05.08\Martarega' 'M. uruguayensis'; Six specimens: 'ARI P3 FA 05.08\Martarega' 'Martarega uruguayensis $\backslash$ (Berg, 1883); One specimen: 'ARI FA 05.08\Martarega' 'M. uruguayensis'; Two specimens: 'ARI P4 FA 02.08 Martarega $\backslash$ uruguayensis'; Two specimens: 'ARI P4 FA 05.08 $\backslash$ Martarega uruguayensis'; One specimen: 'MRI FA P3 02.08 $\backslash$ Martarega' 'M. uruguayensis'; One specimen: 'MRI P3 FA 02.08\Martarega' 'M. uruguayensis'; One specimen: 'MRI P3 PE 02.08 Martarega' 'Martarega uruguayensis'; One specimen: 'MRI FA P1 02.08 $\backslash$ Martarega' 'Martarega uruguayensis'; One specimen: 'BRI P2 FA 04.08 Martarega' 'M. uruguayensis'; One specimen: 'BRI P3 PE 10.08\Martarega' 'M. uruguayensis'; 15 specimens: 'BRI P7 PE $07.08 \backslash$ Martarega' 'M. uruguayensis'; One specimen: 'BRI P5 FA 07.08\Martarega' 'M. uruguayensis'; Eight specimens: 'BRI P7 PE 07.08 Martarega' 'M. uruguayensis'; Two specimens: 'BRI P8 PE 01.08 $\backslash$ Martarega' 'Martarega uruguayensis'; Three specimens: 'BRI P4 PE 10.08\M. uruguayensis'; One specimen: 'P2 PE 09.08 Martarega' 'Martarega uruguayensis'; One specimen: 'P3 FA 09.08 $\backslash$ Martarega' 'Martarega uruguayensis $\backslash$ (Berg, 1883)'; One specimen: 'P2 FA 12.08 \Martarega $\backslash$ M. uruguayensis'; Four specimens: 'BB P2 $\backslash$ PE 03.08' 'M. uruguayensis'; One specimen: 'BB P3 FA 03.08 $\backslash$ Martarega' 'Martarega uruguayensis'; One specimen: 'BB P3 PL 06.08 $\backslash$ Martarega' 'M. uruguayensis'; One specimen: 'BB P2 PE 03.09\Martarega' 'Martarega uruguayensis'.

Notonecta pulchra Hungerford, 1926

Ocurrence: CA.

Three specimens: 'CA P5 PE\Notonecta'.

\section{Pleidae Fieber, 1851}

Neoplea maculosa (Berg, 1879)

Ocurrence: LL.

One specimen: 'P1 PE CA 12.08\Neoplea' 'Neoplea maculosa (Berg, 1879)'.

Neoplea semipicta (Horváth, 1918)

Ocurrence: LA.

Two specimens: 'P5 FA CA 12.08\Neoplea' 'Neoplea $\backslash$ semipicta $\backslash$ (Horváth, 1918). 